\title{
Especially Special: Why Theological Libraries and Librarians Are So Special
}

by Kerrie Stevens

A ccording to many definitions, a special library is any library that is neither an academic, school, public or national library. ${ }^{1}$ I tend to disagree a little with this definition as there are plenty of special academic or school libraries but I get the point - special libraries are not general in nature. "Special libraries often have a more specific clientele than libraries in traditional educational or public settings, and deal with more specialised kinds of information." Special librarians have always known they and their libraries are special - we have to "meet the very unique information needs of special groups of library constituents". 3

Not only are we from special libraries here today, in fact a combination of specific library types (special, academic, school), we are also from a special type of special library - theological libraries. This makes us, in my view, especially special. This is commonly understood amongst our own; the difficulty lies in convincing everyone else of our specialness. But what exactly makes us special? This paper looks at the three main things that make us and our special libraries especially special.

Last year, I asked the ANZTLA Forum for some input, and received a good number of responses to the question 'What makes theological libraries and librarians special?' The reasons I believe our theological libraries and you as theological librarians are special, are discussed below. I aim to provide a summary of the reasons I believe demonstrate why we are especially special. As a side benefit to confirming to you all about your own specialness, I

1 Sylvia James, "Special libraries in the UK," in Encyclopedia of Library and Information Science, ed. Miriam Drake, 2nd ed. (London: CRC Press, 2005), 358.

2 Wikipedia, “Special library,” (2013), http://en.wikipedia.org/wiki/Special_library (accessed 7 June 2013).

3 Paul Kelsey and Sigrid Kelsey eds., Outreach Services in Academic and Special Libraries (New York, NY:

Routledge, 2012), 2. 


\section{"Many law and}

medical libraries

would duplicate

material between

them, but theological

libraries, even

within the same

denomination,

may have many

unique items not

held anywhere else

- something very

special indeed." hope to uplift, edify and encourage you to all go back to workplaces strong in the knowledge that you are indeed a very special resource in your special library, and within your workplace as a whole.

\section{Special Subject}

The first area that I believe makes our libraries and their staff special, is the subject matter of our collections - theology. Theology deals with God and our relationship with Him. Our subject area has eternal consequences, unlike law or medical libraries, which, whilst important, don't concern themselves with anything after we pass on. ${ }^{4}$

Another factor that makes theological libraries special is the fact we have our own classification system - Pettee. Other subject areas also have their own classification systems:

- Moys in law libraries

- NLM - National Library of Medicine Classification scheme in medical libraries

- BCM - British Catalogue of Music Classification Scheme in music libraries

Simply having our own classification scheme available is another aspect of the uniqueness of our collections. Not all theological libraries use it, but it is there nonetheless.

The specialist nature of the theological library collection is similar to those of other subject-specific libraries, given that they specialise the collection on a particular subject area. But it is very different to school libraries which, although special in one sense, have to cover a wide variety of subject matters, thus removing any speciality from their collections as a whole.

A further degree of specialness lies within our collections. Our libraries not only collect materials relevant to the wider theological area, but also focus on materials published by and for our own specific denominations. This means we may hold unique denominational materials or items unique in terms of local expressions of theology. This doesn't necessarily mean materials relevant to other denominations or religions are not collected, but rather that each collection focuses on its own first. A variation of this is the collection that focuses on a topic regardless of the denominational background. The Carmelite Library (VIC) is one such example of this type of collection. Not only does the Carmelite Library collect on spirituality in all the spiritual traditions of Christianity, but also within the other great faith traditions as well. Many law and medical libraries would duplicate material between them, but theological libraries, even within the same denomination, may have many unique items not held anywhere else - something very special indeed.

Theological libraries still rely greatly on the printed word. Medical libraries are very journal article based, whilst law libraries are very electronic. Although there is beginning to be more and more

4 Iris V. Cully and Kendig B. Cully, Harper's Encyclopedia of Religious

Education (San Francisco: Harper \& Row, 1990),648. 
"Some of our

libraries contain

the only copy in

Australia of many

valuable theological

resources, which

make them even

more valuable to

researchers, students

and interested

followers. I'm sure

there might even be

a few items where

our libraries are the

only holding library

in the world - how

exciting is that!" electronic resources available in the theological area, most of our libraries would still collect the majority of materials in print format. Many of our collections would have very old and archived materials that are still very valuable to our patrons today despite being so old; perhaps because they are so old. Ebooks, websites, databases and other electronic resources are becoming more available in the area of theology, which is attractive to many of our patrons, especially those who have been brought up with the internet. However, a large amount of theological resources are historical in nature, and therefore often only available in print format.

Some of our libraries contain the only copy in Australia of many valuable theological resources, which make them even more valuable to researchers, students and interested followers. I'm sure there might even be a few items where our libraries are the only holding library in the world - how exciting is that!

The subject matter of our theological libraries - theology - is a special kind of subject. We are in the business of helping to develop and nurture a life-long relationship with Christ (or other deity) in our students and by default, to indirectly affect all whom they connect with in the future as well. If we do our part in assisting to train the pastors, priests and ministers of tomorrow today, then we play a small, but important part in the conversion, ministry to and development of others in the future. This is a mighty responsibility and one I think we all take quite seriously. We must possess knowledge of a 'myriad of information resources, specialised subject areas and the technology used for acquiring, organising and disseminating information. ${ }^{5}$

\section{Special People}

The second area that assists to define our speciality is our people. Our patrons are here to learn and discover more about their particular subject interest. ${ }^{6}$ Ask any practising pastor or priest, you don't enter that field of employment to make money! Many of our patrons are here because they want to learn more about Christ (or other deity), grow their relationship with Him and, once trained properly, go out into the world and bring more people to know Him. They are not here to get a piece of paper to hang on the wall and make a fortune before they are 35 years old. Many students at regular universities and colleges are there for the prestige of attaining a degree or qualification, or a better, higher-paying job in the future. Our patrons differ to almost every other educational institution in this way. In our theological colleges, they long to be ambassadors for Christ, (or Allah, Buddha etc).

5 Jed Lipinski, “This book is overdue!”: hot for librarian” (1998) http://www. salon.com/2010/02/21/interview_marilyn_johnson_librarians (accessed 14 Dec 2012).

6 Meredith G. Farkas, Social software in libraries: building collaboration, communication, and community online (Medford, NJ: Information Today, 2007), 249. 


\section{"The third area that}

\section{I believe contributes}

greatly to our

specialness is our

theological library

community. Our

theological libraries

are especially

special due to the

collegiality of groups

like our very own

specialist association

- ANZTLA."
Theological libraries are especially special due to the staff that inhabit them - you and I! Being a theological librarian, I believe, is more of a ministry calling than a simple occupation. It demands a "high level of dedication and thoroughness". ${ }^{7}$ Whilst always displaying the extraordinary qualities of librarians, theological librarians also display the ministerial roles of administrator, educator, servant, steward, teacher, counsellor and provider of hospitality. ${ }^{8} \mathrm{We}$ "have to be very versatile". ${ }^{9}$ We are dedicated to our libraries and our patrons, and often extend the extra effort, being dependable and often long-lasting - hands up if you've been in your library for longer than 5 years $\left(2002 \mathrm{ABS}^{10}\right.$ state that $46 \%$ of full-time employees had been at their workplace longer than five years- ANZTLA 2013 Conference rate is above 80\%).

It takes a special person to work in a special library. One with commitment, a strong understanding of their College's beliefs so we can impart and help develop the faith of our patrons. Although many of us don't necessarily personally follow the same religion, or even denomination as that of our theological library, we are still committed to the missions of our respective colleges. "The special librarian doesn't just impact another person, but impacts an entire organization." 11

\section{Special Community}

The third area that I believe contributes greatly to our specialness is our theological library community. Our theological libraries are especially special due to the collegiality of groups like our very own specialist association - ANZTLA. ${ }^{12}$ Every time I have posted a question on our forum, I have always had helpful, enlightening responses and positive encouragement, even if they don't have an answer to my specific question. The sense of community within

7 Heidi Jo Gustad, "Special Libraries" in LIS 6010 Blog, accessed May 21, 2013 http://lis6010blog.blogspot.com.au/2009/06/special-libraries-interesting-thing .html.

8 Kerrie Stevens, "Theological Librarianship: Is It a Ministry Role?," ANZTLA Newsletter 61 (2007):29-39.

9 Maggie Weaver, "What Makes a Special Library 'Special’?," Feliciter 8, no. 3

(2012):.94, accessed June 17, 2013, http://search.proquest.com

/docview/1115095847/fulltextPDF/13EB5EA07B84ECD0AA5

$/ 110$ ? accountid=50932.

10 Australian Bureau of Statistics, "Career Experience, Australia, Nov 2002," accessed May 21, 2013, http://www.abs.gov.au/ausstats/abs@.nsf/mf/6254.0. 11 Jill Hurst-Wahl, and Ruth Kneale, "Special," in The Atlas of New Librarianship, http://www.newlibrarianship.org/wordpress/?page_id=1204 (accessed 21 May 2013).

12 Maggie Weaver, "What Makes a Special Library 'Special'?," Feliciter 8, no. 3 (2012): 94, accessed June 17, 2013, http://search.proquest.com/ docview/1115095847/fulltextPDF/13EB5EA07B84ECD0AA5/110?account id $=50932$. 


\section{"From my own}

experience, we are

a very welcoming,

friendly, encouraging

and non-competitive

association, always

striving to assist

each other to be

better. Let's continue

to be aware of

this and try to

cultivate it at every

opportunity."
ANZTLA is unlike anything I have experienced in my library career, which spans almost 20 years so far. I hope this facet of ANZTLA will continue to develop, grow and expand into the future as people leave or move on, and new ones come into the fold.

Often a post requesting assistance with a tricky enquiry is submitted to the ANZTLA Forum and there are always many responses. I seem to doubt this kind of assistance would be so forthcoming within a law library association, for example, where the competitive advantage over rival law firms must be maintained at all times. ${ }^{13}$ Our members are not afraid to assist when they can, or to even make suggestions of how to find an answer if they don't know it themselves. This is especially helpful given that many of our libraries are staffed by only one or two people, and therefore the ability to discuss with colleagues is not always available. This is something else I hope ANZTLA never loses.

Association membership and involvement allows members to keep "abreast of the latest and best practices in the field." 14 "Participation on committees or holding association offices are ways of obtaining direct leadership experience..."15 Our association acts in an informal mentor/mentoree relationship in which new librarians, those new to theological libraries, or indeed those who have been 'around forever' can connect with each other and work through issues. This sort of dynamic within the association benefits not just the 'mentoree' but also the 'mentor' and the wider membership as well, especially when issues are discussed over the forum with input from a wide variety of contributors.

The ability to develop experience at things such as presentations and publications is a valuable opportunity provided by our association. There are always areas where we can help by offering a little time and the personal rewards far outweigh the costs involved. The chance to present to peers at a conference such as this is a great way to develop presentation skills and the opportunity to write a paper and have it published is an exciting one, and one that is open to anyone.

From my own experience, we are a very welcoming, friendly, encouraging and non-competitive association, always striving to assist each other to be better. Let's continue to be aware of this and try to cultivate it at every opportunity. I hope we all feel our contributions to the association have made "a difference in the professional lives of many library personnel..." ${ }^{16}$ within our association. In the words of

13 Ibid.

14 Mary Wise, "Participation in Local Library Associations: The Benefits to

Participants,” PNLA Quarterly no. 77,1 (Fall, 2012), http://unllib.unl.edu/LPP/

PNLA\%20Quarterly/wise77-1.pdf, accessed May 21, 2013.

15 Ibid.

16 Ibid. 
"So to sum up, the ANZTLA

theological libraries and librarians are

especially special

simply because of

their collections,

their patrons,

the theological

community, but

most especially

because of you -

the theological

librarian!"
Stephen Abram (a past president of SLA), "Librarians change lives. We always have." 17

Our special community is itself made up of many special libraries from a variety of special types of organisations - university, college, school and parish libraries, as well as many others, combine to make up the association as a whole. This allows for a wide variety of perspectives on situations and points of view that we may not have considered before.

\section{Conclusion}

So to sum up, the ANZTLA theological libraries and librarians are especially special simply because of their collections, their patrons, the theological community, but most especially because of you - the theological librarian! In the words of many a thesauri, you are unusual, extraordinary, peculiar, eccentrical, particular, exceptional, tremendous, remarkable, noteworthy, respectable, noble, incomparable, matchless, invincible, unpassable... in other words, SPECIAL.

\section{Bibliography}

Abram, Stephen. "We Are a Profession That Makes a Difference." Information Outlook 13, no. 1 (Jan/Feb 2009): 36-37. Accessed June 17, 2013. http://search.proquest.com/docview/197401515 /fulltextPDF/13EB5EA07B84ECD0AA5

$/ 219$ ? accountid $=50932$

Australian Bureau of Statistics. "Career Experience, Australia, Nov 2002.” (September 22, 2003). Accessed May 21, 2013. http:// www.abs.gov.au/ausstats/abs@.nsf/mf/6254.0.

"British Catalogue of Music Classification Scheme." Accessed May 21, 2013. http://www.slwa.wa.gov.au/_data/assets /pdf_file/0009/3015/Guide_to_the_BCM_Scheme.pdf.

Cully, Iris V. and Kendig B. Cully. Harper's Encyclopedia of Religious Education. San Francisco: Harper \& Row,1990.

Farkas,Meredith G.Social Software in Libraries:Building Collaboration, Communication, and Community Online. Medford, NJ: Information Today, 2007.

Gustad, Heidi Jo. "Special Libraries." In LIS 6010 Blog. Accessed May 21, 2013. http://lis6010blog.blogspot.com.au/2009/06 /special-libraries-interesting-thing.html

Hurst-Wahl, Jill and Ruth Kneale. "Special." In The Atlas of New Librarianship. Accessed May 21, 2013. http://www .newlibrarianship.org/wordpress/?page_id=1204.

17 Stephen Abram, "We are a profession that makes a difference," Information

Outlook, 13.1 (Jan/Feb, 2009): 36-37, http://search.proquest.com

/docview/197401515/fulltextPDF/13EB5EA07B84ECD0AA5

/219? accountid=50932, accessed June 17, 2013. 
James, Sylvia. “Special Libraries in the UK.” In Encyclopedia of Library and Information Science. 2nd ed. Edited by M. Drake. London: CRC Press, 2005.

Kelsey, Paul and Sigrid Kelsey, eds. Outreach Services in Academic and Special Libraries. New York, NY: Routledge, 2012.

Lipinski, Jed. “This Book is Overdue!': Hot for Librarian”. (February 22, 2010). Accessed Dec 14, 2012. http://www.salon .com/2010/02/21/interview_marilyn_johnson_librarians.

McMahon, Melody L. "More Than a Study Hall - The Future of Theological Libraries." Trust Magazine. (Spring 2012). Accessed May 21, 2013. http://ctu.academic.edu /MelodyLaytonMcMahon/Papers/251633.

Stevens, Kerrie. "Theological Librarianship: Is It a Ministry Role?" ANZTLA Newsletter 61 (2007): 29-39.

Weaver,Maggie."WhatMakesaSpecialLibrary'Special'?.”Feliciter58, no. 3 (2012): 91, 94. Accessed June 17, 2013. http:// search.proquest.com/docview/1115095847/fulltextPDF /13EB5EA07B84ECD0AA5/110?accountid=50932.

Wikipedia. "Special Library." Accessed June 7, 2013. http:// en.wikipedia.org/wiki/Special_library. (2013)

Wise, Mary. "Participation in Local Library Associations: The Benefits to Participants." PNLA Quarterly 77, no. 1 (Fall 2012). Accessed May 21, 2013. http://unllib.unl.edu/LPP /PNLA\%20Quarterly/wise77-1.pdf. 